\title{
Teoria reprezentacji społecznych w interdyscyplinarnych badaniach nad dyskursem edukacyjnym - potencjal zbiorowego pisania biografii
}

KEYWORDS

Social Representations Theory, Critical Discourse Analysis, Collective Biography Writing

\begin{abstract}
Zbróg Zuzanna, Teoria reprezentacji społecznych $w$ interdyscyplinarnych badaniach nad dyskursem edukacyjnym - potencjał zbiorowego pisania biografii [The social representations theory in the interdisciplinary study of the educational discourse - the potential of the collective biography writing]. Kultura - Społeczeństwo - Edukacja nr 2(12) 2017, Poznań 2017, pp. 225-243, Adam Mickiewicz University Press. ISSN 2300-0422. DOI 10.14746/kse.2017.12.11.

The aim of the article is to present the theory of social representations which is not well-known in the Polish pedagogy and which may constitute an interesting theoretical and methodological perspective for the study of the educational discourse. The theory itself is interdisciplinary and therefore may be useful in research carried out within various academic disciplines both in the humanities and social sciences. Theoretical analyses will also concern the possibilities of conducting research of educational discourse within the framework of the social representation theory with the application of the collective biography writing which may be perceived as the critical discourse analysis.
\end{abstract}

\section{Wprowadzenie}

Celem artykułu jest przedstawienie mało znanej w polskiej pedagogice teorii reprezentacji społecznych (dalej: TRS), która może stanowić interesującą perspektywę teoretyczną i metodologiczną dla badań nad dyskursem edukacyjnym. Tym 
bardziej, że teoria ta sama w sobie ma charakter interdyscyplinarny, co stanowi o jej dużej przydatności w studiach prowadzonych w ramach różnych dyscyplin naukowych, zarówno z obszaru humanistyki, jak i nauk społecznych. Analizy teoretyczne dotyczyć będą także możliwości prowadzenia badań nad dyskursem edukacyjnym w ramach TRS z wykorzystaniem zbiorowego pisania biografii - metody badawczej, którą można zaliczyć do krytycznej analizy dyskursu (dalej: KAD).

Rzetelne, usystematyzowane i logiczne przedstawienie tych dosyć obszernych i wielowątkowych zagadnień wymagać będzie odwołań do literatury uzupełniającej (w przypisach) - nie sposób bowiem w jednym artykule zawrzeć wszystkich najważniejszych wątków, zwłaszcza jeśli dotyczą zagadnień słabo obecnych w polskich opracowaniach.

\title{
Reprezentacje społeczne jako narzędzie opisu i rozumienia rzeczywistości
}

Twórca TRS, francuski psycholog społeczny Serge Moscovici, zaproponował koncepcję reprezentacji społecznych do analizy sposobu, w jaki teoria naukowa, dotycząca psychoanalizy, przenika do społeczeństwa, odmienia jego język, myślenie i działanie. Moscovici, który świadomie unikał stworzenia jednoznacznej definicji reprezentacji społecznych, opisywał je jako

\begin{abstract}
system wartości, idei i praktyk, spełniających dwojaką funkcję: po pierwsze, ustanawiają one pewien ład zapewniający jednostkom orientację w ich materialnym i społecznym świecie oraz jego opanowanie; po drugie, umożliwiają nawiązanie komunikacji pomiędzy członkami danej społeczności, wyposażając ich w kody służące do wymiany społecznej, a także do nazywania i jednoznacznego klasyfikowania rozmaitych aspektów ich świata oraz jednostkowej i grupowej historii. (Moscovici, 1973: xvii; za: Flick, 2012: 48)
\end{abstract}

W przeciwieństwie do wiedzy naukowej reprezentacje społeczne są wiedzą generowaną przez zdrowy rozsądek ${ }^{1}$. Dzięki niej można próbować zrozumieć "nowe” - nowe idee, kultury, obiekty, zjawiska - poprzez skojarzenie ich z czymś, co jest powszechnie znane. Kiedy coś jest nazwane i klasyfikowane w kategorie, a zatem staje się związane z innymi obiektami tego samego rodzaju, wszyscy człon-

\footnotetext{
${ }^{1}$ Moscovici porównuje reprezentacje społeczne do pnia, z którego wyrastają teorie zdroworozsądkowe, będące „systemami poznawczymi z własną logiką, językiem (...). Społeczne reprezentacje nie reprezentują pojedynczych „opinii o”, „wyobrażeń o” czy „postaw wobec”, ale są „teoriami” czy też „dziedzinami/gałęziami wiedzy”, pozwalającymi na poznanie i ustrukturalizowanie rzeczywistości” (za: Augoustinos, Innes, 1990: 215).
} 
kowie wspólnoty mogą o tym mówić. Reprezentacje pozwalają ludziom zrozumieć rzeczywistość dzięki posiadaniu przez daną społeczność własnych systemów reprezentacji (różnych obiektów i zjawisk, na przykład polityki, szkoły, edukacji) ${ }^{2}$. Członkowie tej samej grupy mogą wypracować reprezentacje, które nie tylko ich łączą ze sobą, ale także prowadzą ich rozumowanie, ukierunkowują i orientują ich działanie. Pomagają im rozumieć świat i ułatwiają życie, bycie w świecie. Reprezentacje społeczne odnoszą się więc do konstruowania własnej zbiorowej rzeczywistości przez określoną grupę społeczną, dla której są one narzędziem „naprowadzania”, kierowania odczytywaniem sytuacji społecznej i działania zgodnie z posiadanymi reprezentacjami.

Reprezentacje społeczne nie powinny być postrzegane jako logiczne i spójne wzorce/schematy myślowe. Dzięki wykorzystaniu koncepcji poznawczej polifazji (ang. cognitive polyphasia) TRS podkreśla fakt, że codzienne myślenie o czymś może być także pełne fragmentów myśli i idei sprzecznych (Jovchelovitch, Priego-Hernandez, 2015). Polifazja odnosi się bowiem do stanu, w którym różne rodzaje wiedzy, charakteryzujące się różnymi racjonalnościami, funkcjonują jednocześnie w umyśle jednostki lub w świadomości społecznej, co wiąże się bezpośrednio z koniecznością pojawienia się elastyczności w komunikacji i pluralizmu w dyskursie publicznym. Według Jovchelovitch (2007) reprezentacje społeczne konstytuują obszary wiedzy, które są w nieustannym ruchu, pokazując, że badacz może koncentrować swoją uwagę na tym, jak różne reprezentacje zderzają się i konkurują w sferze społecznej, jak współistnieją w tym samym kontekście, w tej samej grupie społecznej lub nawet w tej samej jednostce.

Badacze zajmujący się konceptualnie TRS stworzyli definicję reprezentacji społecznych, która w bardziej obrazowy sposób ujmuje ich charakter:

społeczna reprezentacja jest zjawiskiem kolektywnym, odnoszącym się do społeczności, które jest współkonstruowane przez jednostki podczas ich codziennych działań i rozmów. (...) Zamiast wyobrażania sobie reprezentacji [jako zjawiska rezydującego] wewnątrz umysłów, lepiej jest wyobrazić je sobie [jako zjawisko rezydujące] pomiędzy umysłami, przypominające baldachim utkany z połączonych ludzkich rozmów i działań. W skrócie, „społeczna reprezentacja jest zespołem myśli i uczuć, wyrażanych w jawnych i werbalnych zachowaniach aktorów, który konstytuuje obiekt dla grupy społecznej”. (za: Trutkowski, 2007: 339)33

${ }^{2}$ Czytelnicy zainteresowani problematyką reprezentacji społecznych znajdą wiele informacji i przykładów badań w dostępnym online czasopiśmie „Papers on Social Representations”.

${ }^{3}$ Główne tezy TRS można znaleźć w publikacjach polskojęzycznych: Trutkowski 2000; 2007; Niesiobędzka, 2005; Szwed 2011; Zbróg, 2013; 2014; 2015; 2016a; 2016b; 2016c; Krasuska-Betiuk 2014; 2015a; 2015b; 2016; Zbróg Z., Zbróg P., 2016. 


\section{Teoria reprezentacji społecznych jako interdyscyplinarna baza teoretyczna i metodologiczna}

Koncentracja na reprezentacjach zjawisk społecznych i komunikacyjnych czyni TRS bardzo istotną dla badań w obrębie różnych dyscyplin naukowych, ponieważ odnosi się ona do całościowego systemu wiedzy w ramach złożoności świata społecznego (niemożliwej do ujęcia w wąsko wyspecjalizowanych dyscyplinach) ${ }^{4}$. Badacz korzystający z TRS rezygnuje $\mathrm{z}$ wizji świata zamkniętego $\mathrm{w}$ schematach konceptualnych, w analizach zero-jedynkowych. Decyduje się na interpretację obiektów/zjawisk/światów o różnym charakterze, będących w zasięgu jego wzroku. Nie odwołuje się także do transcendentnych kategorii, lecz koncentruje się na obiektach (zjawiskach, światach) umiejscowionych w konkretnym czasie i przestrzeni, choć niemożliwych do wyizolowania $\mathrm{z}$ danego fragmentu świata i jednoznacznego opisu.

Bogusław Śliwerski przekonuje, że „[p]oszukiwanie tożsamości i odrębności każdej z dyscyplin nauk społecznych na podstawie źródeł ich myśli, idei, doktryn czy kierunków mija się z celem, podobnie jak poszukiwanie wyłącznej dla każdej z nich metody badań oraz ich przedmiotu" (Śliwerski, 2016: 31), ponieważ „[r]eprezentanci poszczególnych dyscyplin naukowych włączają poglądy wielu tych samych myślicieli w toku dziejów, aby uzasadnić genezę i odrębność własnej nauki" (Śliwerski, 2016: 30). Tym bardziej, że we wszystkich pokrewnych dyscyplinach z obszaru nauk społecznych przedmiotem badań jest człowiek oraz środowisko jego życia i rozwoju. „Może być on odmiennie ujmowany i w różny sposób obserwowany, jednak nie zmienia to faktu, iż zjawiska społeczne są pewnymi całościami, badanymi przez przedstawicieli różnych dyscyplin z nieco innych pozycji. Badaczy społecznych różnią więc stawiane pytania, a nie przedmiot" (Krauz-Mozer, Ścigaj, 2013: 13). Podobnie rzecz ma się z metodami badań, o których swoistości świadczy właściwie przypisywany im przymiotnik - pedagogiczne, psychologiczne, politologiczne, socjologiczne, a w rzeczy samej są one metodami badań społecznych i/lub humanistycznych. „Metody nie są bowiem funkcją przedmiotu, ale celów badawczych - stawianych pytań i poszukiwanych odpowiedzi" (Krauz-Mozer, Ścigaj, 2013: 13).

Jeśli przyjąć, że pedagogika zajmuje się badaniem szeroko rozumianych procesów edukacyjnych oraz uwarunkowań dyskursu edukacyjnego, to zarówno sam

${ }^{4}$, „W] systemie wiedzy nie istnieją całkowicie niezależne (absolutnie izolowane) dyscypliny. Jeśli obszar badawczy każdej dyscypliny naukowej częściowo pokrywa się z obszarami badawczymi innych dyscyplin, to - ściśle biorąc - nie ma radykalnie monodyscyplinarnych obszarów badawczych" (Poczobut, 2012: 55-56). 
przedmiot, jak i kategorie teoretyczne, z którymi mierzą się pedagodzy, nie pozostawiają wątpliwości, że należy traktować ją jako dyscyplinę otwartą i interdyscyplinarną, w której rozwój swój wkład mają zarówno socjologia, psychologia, filozofia, antropologia, jak i wiele innych dyscyplin. Ponadto pole badawcze pedagogiki/edukacji wykracza często poza to, co jest bezpośrednio obserwowalne, więc jeśli pedagog chce zajmować się rozwiązywaniem złożonych problemów badawczych, musi je charakteryzować z perspektywy interdyscyplinarnej. Tylko wtedy może zrozumieć sieć wielu interakcji specyficznych dla badanego obszaru.

Analizy z wykorzystaniem TRS umożliwiają zastosowanie perspektywy integrującej idee humanistyczne i społeczne, nabierając tym samym charakteru badania interdyscyplinarnego.

\section{Zwiq̨zki teorii reprezentacji społecznych z dyskursem}

Twórca TRS od początku akcentował powiązanie reprezentacji społecznych z procesami komunikacji, uznając język za nośnik reprezentacji społecznych, medium ich przekazywania, uzgadniania i rozpowszechniania. Składnik językowy reprezentacji odnosi je do rzeczywistości zwerbalizowanej, do dyskursu, składnik pozajęzykowy zaś do świata symboli, obrazów, praktyk społecznych, które także przecież mieszczą się w kategorii badawczej dyskursu5. Zarówno język, jak i symbole funkcjonujące $\mathrm{w}$ sferze publicznej stanowią ważne aspekty reprezentacji społecznych, będąc jednocześnie kluczowymi elementami komunikacji i dyskursu - wzajemnie od siebie zależnych, integralnie ze sobą złączonych elementów. Zapewniają one wymianę myśli, wzajemne zrozumienie, gromadzenie informacji, rozpowszechnianie uzgodnionych przekonań, koncepcji, idei, wyobrażeń. Rola języka jako nośnika reprezentacji społecznych nie ogranicza się tylko do funkcji komunikacyjnej, ale związana jest przede wszystkim z procesem nadawania znaczeń rzeczywistości, konstruowania i wyrażania świata, w którym żyjemy.

Moscovici opisał, jak - z jednej strony - reprezentacje społeczne umożliwiają komunikację społeczną, a zwłaszcza porozumienie między grupami społecznymi, a z drugiej strony - zaznaczył, że są one także „produktem dyskursu: dzięki komunikacji reprezentacje przywoływane są do zbiorowej świadomości i reprodukowane” (za: Szwed, 2011: 49). Dyskurs zapewnia wymianę myśli, umożliwia gromadzenie informacji o świecie i upowszechnianie idei, przekonań, wyobrażeń, teorii w formie

\footnotetext{
${ }^{5}$ „Dyskurs prowadzi się nie tylko za pomocą słów, ale i za pomocą strojów, konstruując wystawy w muzeach, urządzając polityczne manifestacje, wypisując recepty w przychodni, zamykając więźnia. Nie sposób wskazać takiej sytuacji, w której dyskurs milknie” (Śpiewak, 2002: 18).
} 
reprezentacji społecznych. „Źródłem społecznych reprezentacji zjawisk, obiektów, problemów, idei jest bowiem krążąca w dyskursie wiedza, która ujawnia się w komunikacji i której kształt jest modyfikowany w zależności od indywidualnych doświadczeń, interesów i przekonań" (Szwed, 2011: 22). Fakt podzielania reprezentacji oznacza, że są one modelowane w procesie społecznej komunikacji, w ramach której wytwarzane i określane są ich wzajemne relacje. Podzielane reprezentacje określają zakres dostępnych nam wzorców interpretacyjnych i jednocześnie konstytuują rzeczywistość, w której żyjemy, stanowiąc współdzielone „modele rzeczywistości”.

TRS jest blisko spokrewniona $\mathrm{z}$ innymi koncepcjami teoretycznymi, ponieważ zajmuje się badaniem wiedzy społecznej, podkreślając znaczenie procesów komunikacyjnych i relacji społecznych w jej tworzeniu. Wielu badaczy próbowało zintegrować TRS z innymi ramami teoretycznymi z zakresu psychologii i nauk społecznych, co zaowocowało połączeniem TRS także z semiotyką, teorią pozycjonowania, teoriami tożsamości, pamięci zbiorowej, poznania społecznego, stereotypów itd. (zob. Zbróg, 2016a). Na przestrzeni lat wypracowano więc różne podejścia empiryczne odpowiadające różnym podejściom teoretycznym w badaniach reprezentacji społecznych, co stwarza duże możliwości analiz i interpretacji w nowych kontekstach. Teoria ta oferuje na przykład nowe podejście umożliwiające pogłębione analizy nad tym, w jaki sposób media i społeczności/grupy społeczne konstruują rozumienie ważnych dla nich kwestii ${ }^{6}$. Zastosowanie TRS jako teoretycznej i metodologicznej bazy pozwala na analizę treści dyskursu publicznego, kontekstu jego wystąpienia, obserwację, za pomocą jakich środków językowych dokonywane są procesy zakotwiczania i obiektyfikacji ${ }^{7}$, a także ustalenie, jakie rezultaty dla działania i sposobu myślenia odbiorców może przynieść określony przekaz medialny. Reprezentacje są bowiem uznawane nie tylko za formę zorganizowania naszej wiedzy o świecie/wiedzy społecznej, ale i za determinanty podejmowanych przez nas działań.

\section{Analiza dyskursu a badanie reprezentacji społecznych}

TRS jest teorią otwartą, która - zgodnie z życzeniem jej twórcy Serge’a Moscoviciego - stale się rozwija stosownie do dynamiki pojawiania się nowej wiedzy. Ta otwartość okazała się zbawienna dla teorii, ponieważ zwolennicy TRS nieustan-

\footnotetext{
${ }^{6} \mathrm{~W}$ polskich badaniach należy wymienić w tym kontekście monografie Cezarego Trutkowskiego (2000), Heleny Ostrowickiej-Miszewskiej (2006) i Roberta Szweda (2011).

7 Te podstawowe mechanizmy komunikacyjne, obserwowane w ramach TRS, opisane są wraz z przykładami analizy w: Trutkowski, 2000; Szwed, 2011; Zbróg 2016 b.
} 
nie prowadzą badania teoretyczne i empiryczne pozwalające na ciągły rozwój tej koncepcji.

Możliwości zastosowania analizy dyskursu jako podejścia badawczego związanego z TRS były wielokrotnie analizowane przez badaczy (McKinlay i in., 1993; Potter, Edwards, 1999; Trutkowski, 2004; Howarth, 2006; Ostrowicka-Miszewska, 2006; Szwed, 2011; van Dijk, 2014; Wodak, Meyer, 2014). Nie od początku związki te były oczywiste. Krytyczna analiza podstawowych różnic między podejściem dyskursywnym i podejściem charakterystycznym dla TRS, przeprowadzona przez Jonathana Pottera i Dereka Edwardsa (1999), stanowiła punkt wyjścia do uregulowania kwestii pominiętych w teoretycznych i empirycznych podstawach TRS (na przykład na temat analizy konwersacji), sprawiających, że TRS okazała się być niewydolna w konceptualizacji działania uwarunkowanego kontekstowo, niedostatecznie dostosowana do pojawiających się nowych metod oglądu rzeczywistości. Podstawowy zarzut kierowany do TRS dotyczył nieuwzględniania złożoności działania i interakcji (Potter, Edwards, 1999: 448-449) oraz traktowania reprezentacji przede wszystkim jako fenomenu poznawczego, obiektu/zjawiska, dzięki któremu ludzie nadają sens światu, mogą go rozumieć, nie są zaś widziane jako obiekty dyskursywne (Potter, Edwards, 1999: 449).

Sprowokowało to badaczy TRS do uwzględnienia w kolejnych opracowaniach teoretycznych i empirycznych zmian niwelujących niedociągnięcia pierwotnej wersji koncepcji. Obecnie TRS stanowi dobrą bazę konceptualną dla badań odpowiadających na pytanie: Co ludzie wiedza (o wybranym obiekcie, zjawisku, procesie), jak o nim myśla i jak w związku z tym działają? (Flick, 2011; Flick i in., 2015). Analizy Wolfganga Wagnera na temat związków reprezentacji społecznych z działaniami udowadniają, że „Ludzie reprezentują obiekty społeczne $w$ działaniu i poprzez działanie" (Wagner, 2015: 22). Najlepszym przykładem (jednym z wielu potwierdzających ustalenia Wagnera) jest badanie etnograficzne w fińskiej szkole podstawowej przeprowadzone przez Kati Kasanen, Hannu Räty i Leilę Snellman (2001), które dostarczyło danych na temat roli działania w procesach mikrogenetycznych związanych z konstruowaniem reprezentacji społecznych. Badaczki te zaobserwowały, że nauczyciele modyfikują układ siedzeń w klasie na podstawie swoich koncepcji „podatności na nauczanie/wyuczalności” (ang. educability). Nowy układ siedzeń wymaga od uczniów bycia posłusznym rekonstrukcji reprezentacji ich pozycji w klasowej hierarchii i dostosowania się do „podatności na kształcenie”. Radzenie sobie z tymi zmianami polega na jawnych działaniach, rozmowach między nimi i sporach z nauczycielem. Rezultaty tego działania (interakcji) mają wpływ na nowe reprezentacje zmienionej sytuacji. Wynik badania pokazał, że modyfikacje reprezentacji przejawianych przez nauczyciela wpłynęły nie tylko na układ siedzeń, ale zmieniły także 
przestrzeń behawioralną dostępną uczniom, co z kolei zmieniło ich reprezentacje. Także wiele innych badań (na przykład Lloyd, Duveen, 1992; Renard i in., 2007) udowadnia, że „Narzucony wzór zostanie w końcu nazwany nową reprezentacją społeczną" (Wagner, 2015: 20), dokładnie tak, jak w wypadku uczniów w przemeblowanej sali. Badani uczniowie zmieniali swoje działania i odzwierciedlali narzucone zmiany sytuacyjne w rozmowie i dyskusji, a więc rozwijali reprezentację społeczną, która sprawiła, że nowość stała się częścią ich zdrowego rozsądku. Potwierdziło to także, że zmiana nie jest wynikiem kontemplacji czy też refleksji własnej, ale zbiorowej dyskusji i działania. To powoduje, że należy działanie traktować jako bazę, fundament pojawiania się nowej reprezentacji. $Z$ analiz wyników empirycznych (więcej na ten temat: Wagner, 2015) można wnioskować, że zmiana reprezentacji na oczekiwane społecznie musi wiązać się z dyskusjami w grupie i z działaniem w nowych okolicznościach. Mamy więc tu do czynienia z teoretyczną wizją reprezentacji podzielanych w grupie i "napędzających”, kierujących działaniami aktorów, wspólnie osiągających cel. Wynika z tego, że „reprezentacje społeczne nie mogą być uważane za konstrukcje jedynie umysłowe" (Wagner, 2015: 27). To nasze działania współkonstruują nasz świat i rzeczywistość, w której funkcjonujemy, tworząc (rekonstruując) nowe reprezentacje.

Dyskursywny charakter materiałów wykorzystywanych w badaniach reprezentacji społecznych spowodował pojawienie się nowych opracowań teoretycznych i empirycznych, uwzględniających fakt, że reprezentacje są dyskursywnymi obiektami, które ludzie konstruują w rozmowie i tekstach jako specyficznych wersjach świata (Potter, Edwards, 1999: 451). Biorąc pod uwagę te ustalenia, do podstawowych (nie jedynych) metod badania reprezentacji społecznych zalicza się takie jakościowe metody zbierania danych, jak wywiady indywidualne i grupowe (zwłaszcza zogniskowane wywiady grupowe tzw. fokusy) czy obserwację uczestniczącą, zaś do powszechnie stosowanych metod analizowania danych należą: analiza dokumentów, analiza konwersacji i analiza dyskursu (Flick i in., 2015; Krasuska-Betiuk, Zbróg, 2017).

Tradycyjne metody analizy konwersacji, dyskursu i dokumentów (na przykład Rapley, 2010) bazują na języku mówionym lub pisanym. Ponieważ termin „analiza dyskursu" jest bardzo wieloznaczny, podejmując się przedstawienia zbiorowego pisania biografii, które może być wykorzystane właśnie do analizy dyskursu, wyjaśnię, że przez analizę dyskursu rozumiem - za Timem Rapleyem - „użycie języka w określonych kontekstach”, przy czym „kontekstem może być zarówno fragment rozmowy, jak i cały okres historyczny" (Rapley, 2010: 22). Skoro język 
nie jest niewinnym, neutralnym i transparentnym środkiem komunikacji, to, jak jest używany, informuje badaczy dyskursu o tym, jak podmioty postrzegają świat i jakie znaczenia nadają opisywanym obiektom.

Z pewnością analiza dyskursu nie może zostać uznana za jednolite, zunifikowane podejście - każda z dyscyplin humanistycznych i społecznych wypracowała bowiem własną terminologię, własne założenia zarówno odnośnie do materiałów do analizy tego, co może zostać uznane za „dane”, jak i do tego, jak przebiega procedura postępowania badawczego.

W badaniu reprezentacji społecznych uwzględnia się zazwyczaj rozumienie dyskursu w ujęciu socjologicznym, jako działanie komunikacyjne oraz jego kontekst związany z sytuacją komunikacyjną, statusem osób komunikujących się i relacjami między nimi. Uwaga badaczy dyskursu koncentruje się na społecznym konstruowaniu rzeczywistości i nadawaniu znaczeń, na języku-w-użyciu, który - jako wytwór ludzkich działań, interakcji, historii, społeczeństwa i kultury - informuje o tym, co jest wykluczane, a co udostępniane w takim, a nie innym opisie rzeczywistości. Pozwala także ustalić obowiązujące podczas tejże komunikacji znaczenia czy hierarchię społeczną (kto lub co ma moc decydującą/władzę), tym samym nawiązując do KAD.

\section{Zbiorowe pisanie biografii ${ }^{8}$ jako szczególny przykład krytycznej analizy dyskursu}

KAD łączy analizę tekstu i wypowiedzi z ustalaniem siły wpływów poszczególnych grup interesów w społeczeństwie, bada występujące w dyskursach przypadki dominacji i nierówności, dyskryminacji i podporządkowania. Celem podejścia krytycznego jest - poza obserwacją, systematyczną deskrypcją i wyjaśnianiem - zmiana rzeczywistości, którą dyskurs opisuje. Służyć temu ma między innymi krytyczna refleksja nad tym, w jaki sposób tworzenie i cementowanie określonej wiedzy i wartości blokuje myślenie o alternatywnych możliwościach i kwestionowanie tego, co wydaje się konieczne i uniwersalne (Fairclough, Wodak, 2006; Ostrowicka, 2015). Krytycznie zorientowana analiza dyskursu zakłada, że:

\footnotetext{
${ }^{8}$ Zbiorowe/Kolektywne/Wspólne Pisanie Biografii (ang. Collective Biography Writing) jest stosunkowo nową metodą badania wspomnień autobiograficznych opracowaną przez australijskie badaczki Bronwyn Davies i Susanne Gannon z University of Western Sydney. W artykule tym nie ma miejsca na przedstawienie szczegółów związanych z podstawami teoretycznymi i procedurą postępowania badawczego stosowaną podczas ZPB. Można się z nią zapoznać w publikacjach: Davies, Gannon, 2006, 2012; Wihlborg, 2013, 2015; Zbróg, 2016d, 2016e, 2016f, 2017a. Przykład analizy z wykorzystaniem ZPB znajduje się w artykule: Zbróg $2017 \mathrm{~b}$.
} 
dyskurs ustanawia przedmioty wiedzy, społeczne tożsamości i relacje między ludźmi. Tym samym, profiluje poznanie i pozycjonuje, wyraża i konstytuuje relacje władzy. W związku z tym, analiza dyskursu staje się narzędziem do badania fenomenów społecznych i kulturowych, a także edukacyjnych. (Ostrowicka, 2014: 52-53)

Ontologiczne podstawy zbiorowego pisania biografii bazują na przekonaniu, że nie istnieje obiektywna rzeczywistość, nie ma obiektywnych relacji, w związku z tym należy raczej analizować konstruowane przez ludzi światy znaczeń i relacji. Celem analiz w ramach zbiorowego pisania biografii nie jest odsłanianie ukrytej "prawdy”, ale zakłócenie tego, co jest brane za pewnik. Celem jest zdestabilizowanie założeń, schematów myślowych, które są uważane za stabilne i niekwestionowane prawdy. To, co uważa się za oczywiste, musi być poddane krytycznej refleksji.

Dostrzegam dużą zbieżność w metodyce prowadzenia badań zbiorowego pisania biografii z KAD. Bazą teoretyczną dla KAD jest poststrukturalizm, zaś zbiorowe pisanie biografii bazuje na krytyce poststrukturalizmu, czyli właściwie „drugim” poststrukturalizmie, dla którego cechą charakterystyczną są studia feministyczne, gender studies, badanie problemów społecznych, zwłaszcza tych, które są związane z władzą i sprawiedliwością (nierówności społeczne, niesprawiedliwość), ale także bycie, stawanie się, uczenie się, co bezpośrednio związane jest już z kategorią dyskursu edukacyjnego. Obecnie trudno jest dokładnie nazwać ten „nowy” trend w rozwoju teorii poststrukturalnej, na co zwracała uwagę między innymi Anna Burzyńska (2002: 83-84), pisząc raczej o orientacji, tendencji do nazywania go zmianami w „mentalności intelektualnej” humanistów, choć właściwie chodzi o zmiany w świadomości badaczy i badanych pod wpływem procesu krytycznego (zob. Zbróg, 2016e).

Uczestnicy zbiorowego pisania biografii, podobnie jak zwolennicy KAD, bezpośrednio wyrażają swoje krytyczne stanowisko, starając się odsłaniać, demistyfikować lub w jakikolwiek inny sposób podważać struktury dominacji ${ }^{9}$. Analizują, w jaki sposób teksty, praktyki i zdarzenia są kształtowane przez relacje władzy. KAD i zbiorowe pisanie biografii koncentrują się na dokładnej analizie używanego języka, na tym, jak język/dyskurs, traktowany jako element władzy, dokonuje przemian społecznego świata, zmienia kulturę danej społeczności. Dyskurs w ramach zbiorowego pisania biografii może być więc rozumiany jako interakcja między jednostką a grupą i utożsamiany z wymianą opinii, debatą, dyskusją (Lisowska-Magdziarz, 2006), przy czym należy zaznaczyć, że metoda biograficzna jest uznawana

${ }^{9}$ O podejściu krytycznym w zbiorowym pisaniu biografii piszą między innymi, odwołując się do krytycznych analiz Foucaultowskich i poststrukturalistycznego dyskursu: Davies i in. (2006: 89 i dalsze), Wihlborg (2013: 385). 
za jedno $\mathrm{z}$ narzędzi analizy interpretatywnej wykorzystywanej w ramach analizy dyskursu (Nowicka, 2016: 179).

Prowadzenie badań metodą KAD realizowane jest najczęściej w trzech etapach, które w ogólnym zarysie odpowiadają analizom prowadzonym w ramach zbiorowego pisania biografii:

- etap pierwszy dotyczy mówionego lub pisanego tekstu będącego przedmiotem badań. Zadaniem badacza jest poznanie tematycznej struktury tekstu oraz jego lingwistyczna analiza;

- drugi etap KAD obejmuje dyskursywne procesy społeczne i polega na analizie odbioru oraz interpretacji tekstu przez ludzi;

- ostatni etap KAD dotyczy socjokulturowych praktyk, czyli badania tego, jakie jest oddziaływanie dyskursu, jakie zmiany w strukturze życia społecznego nastąpiły pod wpływem badanego tekstu (Dobrołowicz, 2013: 117).

W mojej opinii zbiorowe pisanie biografii należy uznać za swoistą metodę badawczą w ramach KAD, której specyfika związana jest przede wszystkim z odmienną formą analizy tekstualnej ${ }^{10}$. Cechą charakterystyczną badań w procedurze zbiorowego pisania biografii jest współuczestniczenie badanych w zbieraniu i interpretacji danych; dane wytwarzane są przez badanych w procesie badawczym, uwzględnia się ich doświadczenia i interpretacje. To jest podstawowa różnica między „typowymi” odmianami KAD i zbiorowym pisaniem biografii, choć - jak wynika z literatury przedmiotu badań - nie jest to sytuacja nadzwyczajna, bowiem „przenikanie się i uzupełnianie kategorii pojęciowych i koncepcji pochodzących $\mathrm{z}$ różnych orientacji teoretycznych jest wyraźne w badaniach nad dyskursem edukacyjnym" (Ostrowicka, 2014: 53).

\section{Możliwości zastosowania zbiorowego pisania biografii do badania reprezentacji społecznych}

Helena Ostrowicka (2014: 51), dokładnie analizując zróżnicowanie teoretyczno-metodologiczne badań określanych mianem analizy dyskursu, stwierdza, że jest ona widziana ,jako zbiór określonych metod, technik i procedur badawczych, któ-

10 Zbiorowe pisanie biografii określane jest jako (innowacyjna) metoda badawcza (research method, Onyx, Small, 2001: 777; Davies, Gannon, 2005: 318; Trahar, 2013: 307; Wihlborg, 2013: 379, 387). Z pewnymi modyfikacjami procedury postępowania badawczego może to być też metoda badania procesu uczenia się (Davies, Gannon, 2006: 5; Trahar, 2013: 307; Wihlborg, 2013; 2015; Zbróg, 2016e, 2016f, 2017b. 
re mogą być dowolnie dobierane dla rozwiązania specyficznych problemów badawczych".

Jak wspomniano wcześniej, TRS jest teorią otwartą, to znaczy każdy badacz może - wraz z rozwojem wiedzy naukowej - dodawać do niej nowe metody, które okażą się skuteczne w badaniu reprezentacji. „Jako teoria, nie metoda, podejście reprezentacji społecznych ma na celu zbadanie sposobów, w jakie jednostki w grupach społecznych rozumieją otaczający ich świat i jak to rozumienie zmienia się, rozwija i oddziałuje" (Flick i in., 2015: 64). Poszukując informacji na temat metod badania reprezentacji społecznych, zwróciłam uwagę na zbiorowe pisanie biografii, które - w mojej opinii - może stać się nową, płodną, dyskursywną metodą badania reprezentacji społecznych.

W zbiorowym pisaniu biografii główny nacisk położony jest na intensywnie odczuwalne, sugestywne wspomnienia, które analizowane są kolektywnie według określonej procedury badawczej (Onyx, Small, 2001; Davies, Gannon, 2006; Zbróg, 2016e, 2017a, 2017b). Zbiorowe analizy opowieści, które następnie są teoretyzowane, doprowadzają do ich nowych znaczeń. Znaczenia działań są bowiem negocjowane „w kontaktach $\mathrm{z}$ innymi ludźmi, zarówno w czasie epizodu (wydarzenia), jak w trakcie refleksji” (Onyx, Small, 2001: 776). Jest to więc tak naprawdę poszukiwanie uzgodnionych społecznie reprezentacji danego zdarzenia czy procesu. Zbiorowe poszukiwanie wspólnego zrozumienia (ang. common understanding) opowieści pozwala dostrzec społeczną naturę konstrukcji wspomnień i - jak wynika z założeń TRS - jest sednem postępowania badawczego identyfikującego reprezentacje społeczne.

Znaczące miejsce w metodyce postępowania badawczego podczas zbiorowego pisania biografii ma koncepcja ucieleśnienia, dość popularna we współczesnych naukach społecznych. Przez ucieleśnienie rozumie się tutaj reprezentację, realizację materialną jakiejś idei, jej widoczną formę, na przykład w postaci uczucia, emocji. Koncepcja ta odnosi się do analizy wspomnień skoncentrowanej na ciele w działaniu, w konkretnym otoczeniu, które jest ustanowione społecznie. Koncepcja ta może być postrzegana jako jeden z nurtów TRS, w którym ciało jest środkiem, poprzez który reprezentacje są wykonywane w praktykach społecznych. W tym sensie reprezentacje społeczne mogą nawet nie być dostępne dla świadomej refleksji. Są one przekazywane poprzez udział w stałych praktykach, gdzie są włączane do ciała (Wagoner, 2015).

Zmysłowa drobiazgowość opisu podczas zbiorowego pisania biografii (tj. z zaangażowaniem odczuć, opisem emocji, zapachów, precyzyjnym i świadomym używaniem języka) prowadzi do tego, że na zasadzie domina u kolejnych członków grupy zaczynają się pojawiać takie same odczucia (wspólnota wzorców odczuwa- 
nia). Wynika to z tego, że ludzie są istotami społecznymi, więc ich relacje oraz reakcje na dane zdarzenie także mają charakter społeczny, właściwie uniwersalny, schematyczny, a więc - jak podkreślę jeszcze raz - o charakterze reprezentacji społecznej danego zdarzenia. Analizy prowadzone w ramach TRS udowadniają, że wraz ze wzrostem komunikacji społecznej i interakcji reprezentacje siebie i świata społecznego stają się bardziej zgodne w swoim charakterze - wśród członków tej samej grupy społecznej ${ }^{11}$.

\section{Badanie zmiany reprezentacji społecznych w trakcie zbiorowego pisania biografii}

Permanentne uczenie się siebie, świata, podejmowanie prób zrozumienia swoich decyzji, znajdowania uzasadnień, doszukiwania się znaczenia swoich działań jest kluczowym warunkiem zmiany swoich przekonań oraz modyfikacji reprezentacji siebie i świata.

Zarys metodyki postępowania badawczego podczas zbiorowego pisania biografii przewiduje najpierw kroki, które mają za zadanie identyfikację reprezentacji społecznych/podzielanej społecznie wiedzy, przekonań, idei. Zwykle teksty poddawane analizom aspirują do bycia obiektywną reprezentacją rzeczywistości. Chodzi więc o odkrycie tego, co jest kulturowo określone/narzucone.

Pierwsza część procedury polega na poszukiwaniu przez członków grupy uogólnień o charakterze stereotypów, imperatywów kulturowych, metafor, na identyfikacji tego, co można uznać za oczywiste, oraz tego, co może podlegać eksplikacji społecznego i kulturowego rozumienia wydarzeń cyklicznych. Omawia się wówczas także koncepcje, popularne powiedzenia i obrazy związane z tematem głównym/obiektem badań po to, aby ponownie zidentyfikować narzucone jako oczywiste, społecznie uwarunkowane wytłumaczenie znaczeń wokół tematu. Wszystko, co stanowi gotowe, od razu nasuwające się wyjaśnienie, wykładnię kulturową powinno na tym etapie być ujawnione.

Komunikację między członkami grupy (w trakcie zbiorowego pisania biografii) postrzega się jako podstawę tworzenia i transmitowania znaczenia. Badacze reprezentacji społecznych są zdania, że „krążą” one w świecie społecznym jako

11 Na przykład badania prowadzone wśród australijskiej młodzieży udowodniły, że wraz z wiekiem wariancja indywidualnych reprezentacji znacząco się zmniejsza. Chociaż - co zrozumiałe nie stwierdzono całkowitego konsensusu, „wraz z postępującą socjalizacją od wieku dojrzewania do wczesnej dorosłości, reprezentacje społeczne stają się bardziej zgodne i podzielane” (Augoustinos i in., 2014: 98). 
wypowiedzi, wyrażenia, słowa, które są wypowiadane albo pisane. Dlatego analityczne badanie dyskursu/języka w świecie społecznym w odniesieniu do identyfikacji reprezentacji społecznych związane jest $\mathrm{z}$ pytaniem o to, jak tworzone są konkretne reprezentacje rzeczywistości, wyszczególniając dyskursywne źródła (zarówno lingwistyczne, jak i pozalingwistyczne), które są podstawą tworzenia takich reprezentacji ${ }^{12}$.

Drugą część postępowania badawczego odnosić można do pracy nad modyfikacją reprezentacji społecznych badanego obiektu. Podstawowym zadaniem podczas zbiorowego pisania biografii jest proces transformacji, w rezultacie którego możemy wyzwolić się ze schematów myślowych, powtórzeń i stereotypowych wyjaśnień, jakie składają się na historię "ja” i historię "moje życie” (Davies, Gannon 2012: 369). W ramach KAD/zbiorowego pisania biografii identyfikowana jest pozycja podmiotu w dyskursie (co także łączy się z TRS i koncepcją pozycjonowania; Harre, Moghaddam, 2015). Określa się również opresyjność działania poszczególnych dyskursów oraz wskazuje sposoby konstruowania przez nie relacji władzy i kontroli społecznej.

\section{Rezultaty pracy analitycznej}

Wynikiem krytycznych analiz jest:

- opis badanego dyskursu;

- ujawnienie sposobu, w jaki dyskurs odzwierciedla relacje władza-wiedza;

- ustalenie stanu wiedzy oraz jawnych i ukrytych przekonań w grupie współbadaczy, wartości i celów, którymi kieruje się grupa, przejawianych stereotypów - innymi słowy ustalenie przejawianych przez grupę reprezentacji społecznych, które decydują o tym, w jaki sposób dyskursy są wykorzystywane do konstruowania społecznej akceptacji zastanego świata. W tej części procesu badawczego zwraca się uwagę także na kwestie przemilczane (ale oczekiwane w związku z opowiedzianą historią). Milczenie na jakiś temat może być także wymownym wskaźnikiem kwestii o głębokim znaczeniu.

${ }_{12}$ Dzięki podejściu charakterystycznemu dla reprezentacji społecznych można obserwować podstawowe mechanizmy komunikacyjne, które wiążą się z procesem tworzenia/modyfikacji reprezentacji społecznych danego obiektu/zjawiska/procesu. Są to zakotwiczanie (nazywanie, zakotwiczanie emocjonalne, zakotwiczanie tematyczne, zakotwiczanie metaforyczne i zakotwiczanie poprzez podstawowe antynomie) oraz obiektyfikacja (emocjonalna i personifikacja). Przykład analizy z wykorzystaniem tych mechanizmów w: Zbróg, 2016b. 
Warsztaty zbiorowego pisania biografii mogą pomóc (wszystkim uczestnikom procesu analityczno-krytycznego) uwolnić się od bezwiednego postępowania zgodnie ze schematami (posiadanymi reprezentacjami społecznymi), które nami kierują, odejść od pewnych mechanizmów, które mamy zinternalizowane. Wpływy społeczne, które nas pozycjonują w określonych bytach, istnieniu w pewnych okowach naszych przekonań, mogą zostać na nowo zinterpretowane po to, żebyśmy mogli ponownie skonstruować nasze rozumienie siebie i świata. Jak mówi Monne Wihlborg, podczas warsztatów zbiorowego pisania biografii „Staramy się uświadomić sobie to, co naprawdę dzieje się w naszym życiu i to, jakie inne rzeczywistości możemy w nim znaleźç" (Wihlborg, 2015: 274). Zbiorowe pisanie biografii pozwala dotrzeć do dostępnego nam repertuaru tworzenia znaczeń, dzięki którym coś (na przykład nasze działanie) nabiera sensu lub przeciwnie, tego sensu nie ma. $Z$ tego punktu widzenia metodę tę można traktować jako metodę uczenia się. Uczymy się bowiem przez oduczanie (ang. learning to unlearn), zrywanie z dotychczasowymi schematami myślowymi (zob. Zbróg, 2016c, 2017b). Proces ten eksponuje odchodzenie od czegoś, czego już kiedyś nauczyliśmy się lub co zostało przez nas nabyte, po to, aby iść w kierunku nowego, krytycznego spojrzenia na otaczającą nas rzeczywistość.

\section{Wnioski}

Na podstawie pierwszych doświadczeń w prowadzeniu badań empirycznych z wykorzystaniem zbiorowego pisania biografii, a także stale pogłębianych dociekań natury teoretycznej i metodologicznej związanych z badaniami prowadzonymi w ramach teorii reprezentacji społecznych, dostrzegam duży potencjał w tej praktyce badawczej. Jest to trudna i złożona metoda, która wymaga bardziej refleksyjnego podejścia niż zazwyczaj w badaniach społecznych (ze względu na partycypację całego zespołu w dekompozycji i dekonstrukcji). Sądzę, że będzie ona coraz częściej stosowana przez badaczy zainteresowanych naukowym obserwowaniem procesu konstruowania podmiotów (podmiotów-w-procesie) ${ }^{13}$ czy też kształtowania naszej podmiotowości w ponowoczesnym świecie. Jej wartość wynika nie tylko ze specyfiki czy też oryginalności samej metody, ale przede wszystkim z potencjału emancypacyjnego, jaki ze sobą niesie. Rezultaty końcowe praktyki badawczej wiążą się bowiem z ujawnianiem opresyjności dyskursu, uczeniem krytycznego namysłu i dostrzega-

${ }^{13}$ Monne Wihlborg twierdzi, że podmiotowość może być analizowana poprzez „zbadanie zmienności różnych pozycji podmiotu dostępnych w ramach dyskursu” (Wihlborg, 2015: 267). 
niem możliwości tkwiących w różnicach. Odkrywanie przez współbadaczy możliwie wszystkich sprzeczności i różnic w omawianych wersjach świata sprzyja negocjacji znaczeń i modyfikowaniu zastanych kulturowo reprezentacji społecznych.

Złożony cel artykułu, jakim było przedstawienie teorii reprezentacji społecznych oraz na tym teoretycznym tle - przybliżenie zbiorowego pisania biografii jako odmiany krytycznej analizy dyskursu, którą można wykorzystać do badania i modyfikacji reprezentacji społecznych, był trudny do osiągnięcia. Opisanie rezultatów moich dociekań teoretycznych $\mathrm{w}$ formie jednego tekstu to przedsięwzięcie skomplikowane ze względu na nie dość dobrze opisane jeszcze w polskiej literaturze zagadnienia: teorii reprezentacji społecznych, a zwłaszcza metody zbiorowego pisania biografii. Formuła i objętość artykułu naukowego nie pozwalają na wyczerpujące uzasadnianie mojego stanowiska badawczego, które za sprawą artykułu poddaję ocenie/weryfikacji potencjalnych Czytelników.

\section{Literatura}

Augoustinos M., Innes J.M. (1990). Towards an integration of social representations and social schema theory. "British Journal of Social Psychology" 29, pp. 213-231.

Augoustinos M., Walker I., Donaghue N. (2014). Social Cognition: An integrated introduction. London.

Burzyńska A. (2002). Poststrukturalizm, dekonstrukcja, feminizm, gender, dyskursy mniejszości i co dalej? „Przestrzenie Teorii” 1, s. 65-86.

Davies B., Browne J., Gannon S., Hopkins L., McCann H. (2006). Constituting the feminist subject in poststructuralist discourse. „Feminism \& Psychology” Vol. 16(1), pp. 87-103.

Davies B., Gannon S. (2005). Feminist/Poststructuralism. [In:] C. Lewin, B. Somekh (eds.), Research Methods in the Social Sciences. Thousand Oaks, CA. pp. 318-325.

Davies B., Gannon S. (eds.) (2006). Doing Collective Biography. Maidenhead.

Davies B., Gannon S. (2012). Collective biography and the entangled enlivening of being. "International Review of Qualitative Research” Vol. 5, No 4, pp. 357-376.

Dobrołowicz, J. (2013). Obraz edukacji w polskim dyskursie prasowym. Kraków.

Fairclough N., Wodak R. (2006). Krytyczna analiza dyskursu. [W:] A. Jasińska-Kania, L.M. Nijakowski, J. Szacki, M. Ziółkowki (wybór i oprac.). Wspótczesne teorie socjologiczne. Warszawa. s. $1047-1056$.

Flick U. (2011). Jakość w badaniach jakościowych, przeł. P. Tomanek. Warszawa.

Flick U. (2012). Projektowanie badania jakościowego, przeł. P. Tomanek. Warszawa.

Flick U., Foster J., Caillaud S. (2015). Researching social representations. [In:] G. Sammut, E. Andreouli, G. Gaskell, J. Valsiner (eds.), The Cambridge Handbook of Social Representations. Cambridge, pp. 64-80.

Harre R., Moghaddam F. (2015). Positioning theory and social representations. [In:] G. Sammut, E. Andreouli, G. Gaskell, J. Valsiner (eds.), The Cambridge Handbook of Social Representations. Cambridge, pp. 224-233. 
Howarth C. (2006). A social representation is not a quiet thing: exploring the critical potential of social representations theory. „British Journal of Social Psychology”, 45(1), s. 65-86.

Howarth D. (2008). Dyskurs, przeł. A. Gąsior-Niemiec. Warszawa.

Jovchelovitch S. (2007). Knowledge in Context: Representations, Community and Culture. London.

Jovchelovitch S., Priego-Hernandez J. (2015). Cognitive polyphasia, knowledge encounters and public spheres. [In:] G. Sammut, E. Andreouli, G. Gaskell, J. Valsiner (eds.), The Cambridge Handbook of Social Representations. Cambridge, pp. 163-178.

Kasanen, K., Räty, H., Snellman, L. (2001). Seating order as a symbolic arrangement. "European Journal of Psychology of Education" 16(2), pp. 209-222.

Krasuska-Betiuk M. (2014). Teoria społecznych reprezentacji w badaniach uczestników praktyk pedagogicznych. [W:] J.M. Łukasik, I. Nowosad, M.J. Szymański (red.). Codzienność szkoły. Nauczyciel. Kraków, s. 175-187.

Krasuska-Betiuk M. (2015a). Interakcje $w$ klasie szkolnej z perspektywy społecznych reprezentacji i oczekiwań interpersonalnych. „Studia z Teorii Wychowania” t. 6, 3, s. 49-77.

Krasuska-Betiuk M. (2015b). Sfera publiczna i edukacja w świetle teorii reprezentacji społecznych. „Forum Oświatowe” 27(1), s. 11-27.

Krasuska-Betiuk M. (2016). Dialog w partnerstwie edukacyjnym: teoretyczne implikacje zastosowania teorii reprezentacji społecznych. [W:] D. Jankowska, M. Grzelak-Klus (red.). Pedagogika dialogu: dialog jako droga rozumienia i samorozumienia. Warszawa, s. 152-163.

Krasuska-Betiuk M., Zbróg Z. (2017). Teoria reprezentacji społecznych Serge’a Moscoviciego. Jakościowe metody zbierania i analizowania danych - część 1. „Przegląd Badań Edukacyjnych” 24(1), s. $173-192$.

Krauz-Mozer B., Ścigaj P. (2013). Sklep z podróbkami? Podejścia badawcze i metodologie w nauce o polityce. [W:] B. Krauz-Mozer, P. Ścigaj (red.). Podejścia badawcze i metodologie w nauce o polityce. Kraków, s. 9-29.

Lisowska-Magdziarz M. (2006). Analiza tekstu w dyskursie medialnym. Kraków.

Lloyd B., Duveen G. (1992). Gender Identities and Education. Hemel Hempstead.

McKinlay A., Potter J., Wetherell M. (1993). Discourse analysis and social representations. [In:] G. Breakwell, D. Canter (eds.), Empirical Approaches to Social Representations. Oxford, pp. 134-156.

Moscovici S. (2000). Social Representations. Explorations in Social Psychology. Cambridge.

Niesiobędzka, M. (2005). Reprezentacje społeczne zjawisk ekonomicznych. Białystok.

Nowicka M. (2016). O użyteczności kategorii dyspozytywu w badaniach społecznych. „Przegląd Socjologii Jakościowej" t. XII, nr 1, s. 170-191.

Onyx J., Small J. (2001). Memory-work: the method. "Qualitative Inquiry" Vol. 7 No 6, pp. 773-786.

Ostrowicka H. (2014). Kategoria dyskursu w jezzyku i w badaniach edukacyjnych - w poszukiwaniu osobliwości pedagogicznie zorientowanej analizy dyskursu. „Forum Oświatowe” 2(52), s. 47-68.

Ostrowicka H. (2015). Przemyśleć z Michelem Foucaultem edukacyjne dyskursy o młodzieży. Dyspozytyw i urządzanie. Kraków.

Ostrowicka-Miszewska H. (2006). „Jak porcelana rzucona o beton...”. Dyskursy o młodzieży, polityce i polityce młodzieży. Kraków.

Poczobut R. (2012). Interdyscyplinarność i pojęcia pokrewne. [W:] A. Chmielowski, M. Dudzikowa, A. Grobler (red.), Interdyscyplinarnie o interdyscyplinarności. Między idea a praktyką. Kraków, s. 39-63.

Potter J., Edwards D. (1999). Social representations and discursive psychology: from cognition to action. "Culture and Psychology" 5(4), pp. 447-458. 
Rapley T. (2010). Analiza konwersacji, dyskursu i dokumentów. Przeł. A. Gąsior-Niemiec. Warszawa. Szwed R. (2011). Reprezentacje opinii publicznej $w$ dyskursie publicznym. Lublin.

Śliwerski B. (2016). Uwikłania pedagogiki w naukach społecznych. „Ruch Pedagogiczny” 2, s. 29-40. Śpiewak P. (2002). Słowa modne i niemodne (słownik). „Res Publica Nowa” 10, 18.

Trahar S. (2013). Contemporary methodological diversity in European higher education. „European Educational Research Journal" 12(3), pp. 301-309.

Trutkowski C. (2000). Społeczne reprezentacje polityki. Warszawa.

Trutkowski C. (2004). Wybór czy konieczność - o potrzebie wykorzystania analizy dyskursu w socjologii. „Kultura i Społeczeństwo” 1, s. 35-50.

Trutkowski, C. (2007). Teoria społecznych reprezentacji i jej zastosowania. [W:] M. Marody (red.), Wymiary życia społecznego. Polska na przełomie XX i XXI wieku. Warszawa, s. 327-356.

Van Dijk T.A. (2014). Critical Discourse Studies: a Sociocognitives Approach. [In:] R. Wodak, M. Meyer (eds.), Methods of Critical Discourse Studies. London, pp. 62-85.

Wagner W. (2015). Representation in action. [In:] G. Sammut, E. Andreouli, G. Gaskell, J. Valsiner (eds.). The Cambridge Handbook of Social Representations. Cambridge, pp. 12-28.

Wagoner B. (2015). Collective remembering as a process of social representation. [W:] G. Sammut, E. Andreouli, G. Gaskell, J. Valsiner (eds.). The Cambridge Handbook of Social Representations. Cambridge, pp. 143-162.

Wihlborg M. (2013). Using a process of collective biography writing in higher education to develop an ability to explore, reveal and critically reflect. "European Educational Research Journal" 12(3), pp. 376-388.

Wihlborg M. (2015). An awareness of the feminist subject: an example of collective biography writing in poststructuralist discourse practice. [In:] P. Smeyers, D. Bridges, N.C. Burbules, M. Griffiths (eds.). International Handbook of Interpretation in Educational Research. Dordrecht-Heidelberg-New York-London, pp. 257-280.

Wodak R., Meyer M. (2014). Critical Discourse Studies: History, Agenda, Theory and Methodology. [In:] R. Wodak, M. Meyer (eds.), Methods of Critical Discourse Studies. London, pp. 1-22.

Zbróg Z. (2013). Badanie społeczności/zjawisk społecznych $z$ wykorzystaniem (elementów) teorii reprezentacji społecznych - perspektywa pedagogiczna. „Pedagogika. Badania, dyskusje, otwarcia. Specyfika pomiaru w badaniach społecznych” 2, s. 45-60.

Zbróg Z. (2014). Reprezentacje społeczne praktyk pedagogicznych - konstruowanie profesjonalizmu wykładowców, nauczycieli i studentów. [W:] J. Piekarski, E. Cyrańska, B. Adamczyk (red.). Doskonalenie praktyk pedagogicznych - dyskusja. Łódź, s. 65-80.

Zbróg Z. (2015). The episodic-narrative interview as a method of research of social representations. „Acta Universitatis Matthaei Belii”. Banska Bystrica, s. 41-51.

Zbróg Z. (2016a). Teoria reprezentacji społecznych $w$ badaniach zmiany szkoły - możliwe zastosowania. [W:] M.J. Szymański, B. Walasek-Jarosz, Z. Zbróg (red.). Zrozumieć szkołę. Konteksty zmiany. Warszawa, s. 226-249.

Zbróg Z. (2016b). Obniżenie wieku rozpoczęcia obowiązku szkolnego - reprezentacje społeczne problemu $w$ debacie publicznej. „Problemy Wczesnej Edukacji” 4(35), s. 85-93.

Zbróg Z. (2016c). Uczenie się przez oduczanie - modyfikowanie reprezentacji społecznych przyszlych nauczycieli. „Pedagogika Szkoły Wyższej” 1, s. 95-107.

Zbróg Z. (2016d). Collective Biography Writing - Theoretical Foundations Methods and Outline of the Research Procedure. „The New Educational Review,” vol. 43, nr 1, s. 287-294. 
Zbróg Z. (2016e). Uczenie się „stawania się” świadomym badaczem - zbiorowe pisanie biografii jako przykład metody badania dyskursów. „Zagadnienia Naukoznawstwa” 2 (208), s. 233-250.

Zbróg Z. (2016f). Poznawanie siebie podczas zbiorowego pisania biografii (z teoria reprezentacji społecznych w tle). [W:] M. Krasuska-Betiuk, M. Jabłonowska, S. Galanciak (red.). O poszukiwaniu, poznawaniu i tworzeniu samego siebie. Warszawa, s. 55-63.

Zbróg Z. (2017a). Podmiot-w-procesie. Poststrukturalistyczna analiza wspomnień w grupach studenckich metoda zbiorowego pisania biografii, „Kwartalnik Pedagogiczny” 2, s. 56-72.

Zbróg Z. (2017b). Zbiorowe pisanie biografii jako metoda uczenia się o sobie, o innych, o świecie. „Studia Edukacyjne” 46, s. 357-372.

Zbróg Z., Zbróg P. (2016). Reprezentacje społeczne jako nośniki pamięci zbiorowej. „Horyzonty Wychowania" 2, s. 11-27. 